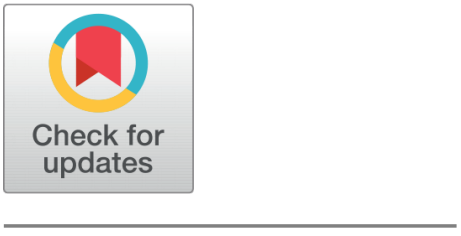

OPEN ACCESS

Received: 03.10.2020

Accepted: 23.11 .2020

Published: 03.12.2020

Citation: Prof (Dr.) Anil Vashisht, Harendra Singh (2020) Usage of rainfall derivatives to hedge rainfall risk: A feasibility study of Gwalior Chambal region. Indian Journal of Science and Technology 13(42): 4369-4373. https://doi.org/ 10.17485/IJST/V13i42.1771

* Corresponding author.

hsingh@gwa.amity.edu

Funding: None

Competing Interests: None

Copyright: ( $) 2020$ Prof (Dr.) Anil Vashisht \& Harendra Singh. This is an open access article distributed under the terms of the Creative Commons Attribution License, which permits unrestricted use, distribution, and reproduction in any medium, provided the original author and source are credited.

Published By Indian Society for Education and Environment (iSee)

ISSN

Print: 0974-6846

Electronic: 0974-5645

\section{Usage of rainfall derivatives to hedge rainfall risk: A feasibility study of Gwalior Chambal region}

\author{
Prof (Dr.) Anil Vashisht ${ }^{1}$, Harendra Singh ${ }^{2 *}$ \\ 1 Deputy-Pro VC, Director, Amity Business School, Amity University, Madhya Pradesh \\ 2 Assistant Professor, Amity Business School, Amity University, Madhya Pradesh
}

\section{Abstract}

Objectives: To check the awareness level of farmers towards crop insurance schemes available so far and their satisfaction level with those schemes. To check the acceptability of farmers towards rainfall derivatives Methods: To achieve the objective of study, we have conducted a survey among the farmers of Gwalior Chambal region in India. The sample size of survey was 470 farmers; we have selected 5 villages per tehsil and 2 farmers per village. We have used cross tabulation to analyse the collected data. Findings: This study shows that only few farmers were aware about the previously launched crop insurance schemes by government and out the farmers who were aware and used the previous schemes were not satisfied with them. This study also shows the positive response by farmers towards rainfall derivative products. The study shows that most of the farmers believed that rainfall derivative can be a very effective tool for hedging the rainfall risk. Novelty : This study is very much helpful to understand the acceptability of rainfall derivatives among the farmers of Gwalior-Chambal region. This study can be used as a recommendation to launch the rainfall derivatives in India.

Keywords: Rainfall risk; rainfall derivatives; crop insurance; hedging; weather index-based insurance; crop damage

\section{Introduction}

India is agricultural driven economy where most part of population depends on agriculture production for their livelihood. Unfortunately large part of agricultural production still depends on good monsoon conditions so the agricultural production is very uncertain in volatile monsoon conditions. The uncertain monsoon conditions not only affect the farmers but also other industries, which are directly or indirectly depends on agricultural production.

Small and poor farmers are affected more by bad weather conditions; their income depends on good monsoon. Poor farmers had to sell their assets, livestock in case of low agricultural yield due to bad monsoon. Government of India is very concern about the farmers and continuously trying to introduce the risk hedging tools to mitigate this risk. In the past, government has provided several insurance products like Comprehensive crop insurance scheme (CCIS), National agricultural insurance 
scheme (NAIS), Pradhan mantri fasal beema yojana (PMFBY) etc. but these programs were not much successful.

The main causes of the failure of such schemes are involvements of much paper work, high premium cost, need to prove the loss of crop due to bad weather conditions which is very tedious task. The rainfall derivative may solve these problems as in case of derivative products the premium amount is very less or zero, it does not have much paper work and in case of derivative production the party don't need to prove the loss only occurrence of specified event is sufficient to release the fund.

Some studies show the rainfall based insurance products in developing country like Mexico ${ }^{(1)}$. In their research work they have tested the correlation between the rainfall and agricultural production to identify the loss in production due to bad rainfall. They used a dummy rainfall product and have studied the how this dummy product effect the income of farmers by change in agriculture production. This research also indicated that rainfall products work well in the areas where the correlation rainfall and farm production is significant.

While other studies shows the effectiveness of weather derivative products to hedge the rainfall risk ${ }^{(2)}$. They have also studied the potential use of these derivative products in Portugal. They have identified that for development of weather derivatives in any country we need a good legal framework, good infrastructure, efficient regulating bodies, proper training of participants etc. these factors will help in rapid growth of weather derivatives.

One of the researchers has checked the feasibility of derivative products in Indian perspective ${ }^{(3)}$. The researcher has studied different other rainfall risk hedging tools and reasons for their failure in Indian market. The author has discussed several crop insurance products and reasons of their failure in Indian perspective. The major reason of the failure of such crop insurance programme is their premium amount which is not attractive for poor farmers. She has also given weightage to good regulating framework and investor's education towards weather derivative products.

Late advancements in vitality markets propose the chance of tending to agrarian danger factors by giving subordinates on climate components. Such instruments show up especially appealing, as lopsided data and misfortune change issues don't influence them. This article initially depicts the idea, working and utilization of climate subsidiaries. It at that point inspects the practicality of precipitation subsidiaries to oversee rural creation danger in South Africa by assessing the benefits of precipitation choices, and proposing a choice technique, as a yield hazard the board device. The utilization of precipitation subsidiaries in South Africa is probably going to increment in future as capital business sectors, money related foundations, insurance agencies, crop insurance agencies and speculative stock investments altogether sort out themselves to share and appropriate climate chances ${ }^{(4)}$.

As of late, one of the variables that significantly affected the financial advancement was spoken to by climatic change. At worldwide level, the climate hazard the executives represents a need for Governments, insurance agencies and organizations inside the enterprises influenced by the climate changeability. Inside this article, we attempt to address a more appropriate methodology than the protection approaches on the matter of climate hazard the board by introducing an imaginative elective danger the executives arrangement spoke to by climate subsidiaries. Besides, they focus upon a significant financial segment the agribusiness by underlining the particular angles with respect to the work of climate subsidiaries ${ }^{(5)}$.

The impacts of climate on agribusiness as of late have become a significant worldwide concern. Thus, a compelling climate hazard the board instrument (i.e., climate subordinates) that can support crop yields against climate vulnerabilities is required. Be that as it may, most smallholder ranchers and horticultural partners are reluctant to follow through on for the cost of climate subsidiaries (WD) due to the presence of premise chances (item plan and geological) in the evaluating models. To wipe out item plan premise hazards, an AI outfit method was utilized to decide the connection between maize yield and climate factors. The outcomes uncovered that the most huge climate variable that influenced the yield of maize was normal temperature. A mean-returning model with a period differing rate of mean inversion, occasional mean, and neighbourhood instability that relied upon the nearby normal temperature was then proposed ${ }^{(6)}$.

Weather derivatives speak to a significant budgetary development for hazard the board. Likewise with the utilization of any derivative contract, the conduct of the premise eventually decides the net-supported result. Be that as it may, when utilizing climate subsidiaries to fence volumetric dangers, hazard chiefs regularly face interesting premise chances emerging from both the decision of climate station where a derivative contract is composed, just as the connection between the supported volume and the hidden climate list. Utilizing the incorporating standard, this exploration shows that the nonlinear relationship regularly found between crop yields and climate makes a particular supporting function for choices. The outcomes recommend that climate subsidiary instruments with nonlinear adjustments, for example, alternatives, be utilized exclusively or in mix with straight result instruments, for example, trades or fates, to limit premise hazard related with the nonlinear connection among yields and climate. This exploration additionally proposes that the decision of climate station might be less basic in overseeing premise hazard than appropriately representing the connection among yields and climate ${ }^{(7)}$.

Climate based crop insurance is also a very powerful tool available for farmers to hedge the rainfall risk they are based on rainfall index and provide the pay-out based on the changes in weather parameters ${ }^{(8)}$. Small farmers are highly affected with 
adverse climate conditions and due to less cost the weather derivatives will help small scale farmers also to hedge the rainfall risk ${ }^{(9)}$. Weather index-based insurance plans are picking up consideration as instruments for agricultural risk management. A critical distinction between these protection plans and more customary ones is that the previous can adapt all the more viably to antagonistic determination and good peril issues, yielding more affordable protection contracts ${ }^{(10)}$.

The rainfall derivative market is not yet developed in India, and we need to check the acceptability of rainfall derivatives among the farmers so that the recommendation can be given to government to introduce such products. We have conducted a survey among the farmers of Gwalior-Chambal region to check the acceptability of rainfall derivatives and their willingness to pay for these products.

\section{Research Methodology}

\section{Objective of the study}

1. To check the awareness level of farmers towards crop insurance schemes available so far and their satisfaction level with those schemes.

2. To check the acceptability of farmers towards rainfall derivatives

To achieve the above objective we have conducted the survey among the farmers and adopted the following methodology

Sample size: The survey was conducted among the 470 farmers of Gwalior Chambal region we have selected 5 villages per tehsil and 2 farmers per village. The Gwalior Chambal region has 8 districts Ashoknagar, Bhind, Datia, Guna, Gwalior, Morena, Sheopur, Shivpuri.

Sampling design: judgemental sampling is used.

Statistical tool: We have used cross tabulation to analyse the collected data.

\section{Result and Discussion}

In the survey we have asked the farmers about their experience about the previous insurance schemes and come to know that around $61 \%$ of farmers were not aware about the previous schemes. We have then asked the experience of farmers who were aware and have used previous insurance products. Table 1 shows the experience of farmers with previous schemes.

It is clearly visible in the table that most of the farmers (87.5\%) were not satisfied with the previous insurance product used by them ( $60.1 \%$ were unsatisfied and $27.9 \%$ were highly unsatisfied). These farmers were also asked about the reasons for their dissatisfaction from earlier schemes and in response 52\% said area approach adopted in these schemes and $37 \%$ said that the insurance schemes take much time to pay for the settlement. $65 \%$ of farmers said that the process adopted by companies for settlement is unfair and not clear to them. Most of the farmers (53.3\%) said that they had to pursue personally for the settlement of the claim.

Table 1. Experience with earlier insurance schemes

\begin{tabular}{|c|c|c|c|c|c|c|c|c|c|c|}
\hline \multirow{2}{*}{ District } & \multicolumn{2}{|c|}{ Satisfied } & \multicolumn{2}{|c|}{ Can't say } & \multicolumn{2}{|c|}{ Unsatisfied } & \multicolumn{2}{|c|}{ Highly unsatisfied } & \multicolumn{2}{|c|}{ Total } \\
\hline & $\mathrm{N}$ & $\%$ & $\mathrm{~N}$ & $\%$ & $\mathrm{~N}$ & $\%$ & $\mathrm{~N}$ & $\%$ & $\mathrm{~N}$ & $\%$ \\
\hline Ashoknagar & 0 & $0.0 \%$ & 0 & $0.0 \%$ & 18 & $66.7 \%$ & 9 & $33.3 \%$ & 27 & $100 \%$ \\
\hline Bhind & 4 & $11.1 \%$ & 0 & $0.0 \%$ & 26 & $72.2 \%$ & 6 & $16.7 \%$ & 36 & $100 \%$ \\
\hline Datia & 1 & $5.9 \%$ & 1 & $5.9 \%$ & 10 & $58.8 \%$ & 5 & $29.4 \%$ & 17 & $100 \%$ \\
\hline Guna & 1 & $4.8 \%$ & 6 & $28.6 \%$ & 9 & $42.9 \%$ & 5 & $23.8 \%$ & 21 & $100 \%$ \\
\hline Gwalior & 0 & $0.0 \%$ & 2 & $16.7 \%$ & 5 & $41.7 \%$ & 5 & $41.7 \%$ & 12 & $100 \%$ \\
\hline Morena & 0 & $0.0 \%$ & 0 & $0.0 \%$ & 20 & $64.5 \%$ & 11 & $35.5 \%$ & 31 & $100 \%$ \\
\hline Sheopur & 0 & $0.0 \%$ & 0 & $0.0 \%$ & 15 & $68.2 \%$ & 7 & $31.8 \%$ & 22 & $100 \%$ \\
\hline Shivpuri & 1 & $5.9 \%$ & 6 & $35.3 \%$ & 7 & $41.2 \%$ & 3 & $17.6 \%$ & 17 & $100 \%$ \\
\hline Total & 7 & $3.8 \%$ & 15 & $8.2 \%$ & 110 & $60.1 \%$ & 51 & $27.9 \%$ & 183 & $100 \%$ \\
\hline
\end{tabular}

Source: Data collected by survey

We have explained the concept of weather derivatives to farmers and how it is different than other insurance products. We have told them that rainfall derivatives are much cheaper as compare to insurance products, the pricing of derivative products and their claim settlement process is much transparent as contrast with derivative products, the derivative products can be purchased and sold any time etc. 
Table 2 shows response of farmers towards the rainfall derivatives. 93.4\% farmers agreed that these products will be useful in relieving financial stress. It shows that farmers are ready to adopt the rainfall derivatives products to hedge the rainfall risk.

Table 2. Do you think rainfall derivatives as explained could help in relieving financial stress?

\begin{tabular}{|c|c|c|c|c|c|c|c|c|c|c|c|c|}
\hline \multirow[t]{2}{*}{ District } & \multicolumn{2}{|c|}{$\begin{array}{l}\text { Would help to a very } \\
\text { large extent }\end{array}$} & \multicolumn{2}{|c|}{$\begin{array}{l}\text { Would help to a } \\
\text { fair extent }\end{array}$} & \multicolumn{2}{|c|}{$\begin{array}{l}\text { Would help } \\
\text { marginally }\end{array}$} & \multicolumn{2}{|c|}{ Might not help } & \multicolumn{2}{|c|}{$\begin{array}{l}\text { Am sure will not } \\
\text { help }\end{array}$} & \multicolumn{2}{|c|}{ Total } \\
\hline & $\mathrm{N}$ & $\%$ & $\mathrm{~N}$ & $\%$ & $\mathrm{~N}$ & $\%$ & $\mathrm{~N}$ & $\%$ & $\mathrm{~N}$ & $\%$ & $\mathrm{~N}$ & $\%$ \\
\hline Ashoknagar & 31 & $62.0 \%$ & 11 & $22.0 \%$ & 5 & $10.0 \%$ & 1 & $2.0 \%$ & 2 & $4.0 \%$ & 50 & $100 \%$ \\
\hline Bhind & 50 & $62.5 \%$ & 17 & $21.3 \%$ & 8 & $10.0 \%$ & 1 & $1.3 \%$ & 4 & $5.0 \%$ & 80 & $100 \%$ \\
\hline Datia & 25 & $62.5 \%$ & 8 & $20.0 \%$ & 6 & $15.0 \%$ & 1 & $2.5 \%$ & 0 & $0.0 \%$ & 40 & $100 \%$ \\
\hline Guna & 36 & $51.4 \%$ & 21 & $30.0 \%$ & 9 & $12.9 \%$ & 1 & $1.4 \%$ & 3 & $4.3 \%$ & 70 & $100 \%$ \\
\hline Gwalior & 8 & $20.0 \%$ & 22 & $55.0 \%$ & 1 & $2.5 \%$ & 2 & $5.0 \%$ & 7 & $17.5 \%$ & 40 & $100 \%$ \\
\hline Morena & 41 & $68.3 \%$ & 11 & $18.3 \%$ & 7 & $11.7 \%$ & 0 & $0.0 \%$ & 1 & $1.7 \%$ & 60 & $100 \%$ \\
\hline Sheopur & 32 & $64.0 \%$ & 9 & $18.0 \%$ & 7 & $14.0 \%$ & 1 & $2.0 \%$ & 1 & $2.0 \%$ & 50 & $100 \%$ \\
\hline Shivpuri & 35 & $43.8 \%$ & 38 & $47.5 \%$ & 1 & $1.3 \%$ & 4 & $5.0 \%$ & 2 & $2.5 \%$ & 80 & $100 \%$ \\
\hline Total & 258 & $54.9 \%$ & 137 & $29.1 \%$ & 44 & $9.4 \%$ & 11 & $2.3 \%$ & 20 & $4.3 \%$ & 470 & $100 \%$ \\
\hline
\end{tabular}

Source: Data collected by survey

\section{Conclusion}

The findings of survey conducted in Gwalior-Chambal region states that most of the farmers (61\%) were not fully aware about the earlier schemes launched by government of India and some farmers (39\%), who have used the schemes were not satisfied with the schemes. The reasons of dissatisfaction of farmers from previous insurance schemes are large premium amount, lack of transparency, slow process of claim settlement. The major reasons of dissatisfaction of farmers from previous insurance schemes were large premium amount, lack of transparency, slow process of claim settlement etc. As per this study most of the farmers (93.4\%) believed that rainfall derivatives would be very useful in relieving financial stress as these products have low premium, more transparency, and fast pay-out.

In future this study can be extended further in other meteorological region of India to study the acceptability of farmers towards rainfall derivatives and their willingness to pay. We can develop suitable pricing model for rainfall derivatives.

Limitation of study: The respondents in our survey were farmers of Gwalior-Chambal region and most of the farmers are either not much educated or not aware about the possibilities of rainfall risk hedging. Although we have made an attempt to educate the farmer about the rainfall derivatives, before the survey yet this might not be enough to give them proper understanding of these products.

\section{References}

1) Skees JR, Gober S, Varangis P, Lester RR, Kalavakonda V. Developing rainfall-based index insurance in Morocco Policy Research Working Paper;No. 2577. World Bank, Washington, DC. Washington, DC. World Bank. 2001. Available from: http://documents.worldbank.org/curated/en/620921468776967663/ pdf/multi0page.pdf.

2) Ghiulnara A, Viegas C. Introduction of weather-derivative concepts: perspectives for Portugal. The Journal of Risk Finance. 2010;11(1):9-19. Available from: https://dx.doi.org/10.1108/15265941011012660.

3) Choksi A. Emergence of Weather Derivatives - Feasibility in Indian Context. Zenith International Journal of Business Economics \& Management Research. 2012;2(5):139-152. Available from: http://www.zenithresearch.org.in/images/stories/pdf/2012/May/ZIJBEMR/11_ZIBEMR_VOL2_ISSUE5_MAY2012. pdf.

4) Geyser JM. Weather Derivatives: Concept and application for their use in South Africa. Agrekon. 2004;43(4):444-464. Available from: https: //dx.doi.org/10.1080/03031853.2004.9523660.

5) Hurduzeu G, Constantin LG. Several Aspects Regarding Weather and Weather Derivatives. Romanian Economic Journal. 2008;11(27):187-202.

6) Gyamerah SA, Ngare P, Ikpe D. Hedging Crop Yields Against Weather Uncertainties-A Weather Derivative Perspective. Mathematical and Computational Applications. 2019;24(3):71-71. Available from: https://dx.doi.org/10.3390/mca24030071.

7) Manfredo MR, Richards TJ. Hedging with weather derivatives: a role for options in reducing basis risk. Applied Financial Economics. 2009;19(2):87-97. Available from: https://dx.doi.org/10.1080/09603100701765166.

8) Shirsath P, Vyas S, Aggarwal P, Rao KN. Designing weather index insurance of crops for the increased satisfaction of farmers, industry and the government. Climate Risk Management. 2019;25. Available from: https://dx.doi.org/10.1016/j.crm.2019.100189.

9) Ward PS, Makhija S, Spielman DJ. Drought-tolerant rice, weather index insurance, and comprehensive risk management for smallholders: evidence from a multi-year field experiment in India. Australian Journal of Agricultural and Resource Economics. 2020;64(2):421-454. Available from: https: //dx.doi.org/10.1111/1467-8489.12342. 
10) Nogales R, Cordova P. On the Advantages and Feasibility of Weather Index-Based Crop Insurance Schemes in Bolivia. . 2019. Available from: https://doi.org/10.1080/1540496x.2019.1677226. 